\title{
Identification of Bacteria from under Finger Nails
}

\author{
Saloni Singh, Dr. Jaya Philip, Kumari Nidhi, Pallavi Kumari, Shagufta Akhtar, Khushboo Kumari \\ Patna Women's College, Patna, Bihar, India
}

\begin{abstract}
Article Info
Volume 7, Issue 6

Page Number: 234-241

Publication Issue :

November-December-2020
\end{abstract}

\section{Article History}

Accepted : 15 Nov 2020

Published : 25 Nov 2020

\section{ABSTRACT}

This study was conducted to isolate and identify bacteria from human finger nails. A total of three nail samples were collected. The samples were collected from random people in which two of them were from females and one was from male. The isolated pathogens from finger nails include Bacillus species (2 isolates), coccus species (one isolate). Highest contamination of Bacillus species was isolated. After the colonies were being isolated, they were further characterized on the basis of biochemical characteristics including Indole test, Citrate test, Nitrate reduction test and Urease test. After that Antimicrobial susceptibility tests were performed to identify the resistance of a particular bacteria towards a given antibiotic i.e. Ampicillin, Chloromphenicol, Norfloxacin, Co-Trimoxazol and Ciprofloxacin. However the results obtained showed the resistance of isolates towards Ampicillin indicating the prevalance of potentially disease causing microbes under fingernails. This study showed the importance of nail hygiene.

Keywords : Bacteria, Isolate, Microbes, Fingernails, Sterilized, Nutrient Agar, Incubated, Test, Inoculum, Colonies.

\section{INTRODUCTION}

Microorganisms are widely distributed all over the world be it air, water, soil and even human body. Human body is said to be the shelter of millions of bacteria, viruses, fungi, and other many other invisible organisms. These organisms are collectively called as microbes. The microbes belong to different communities and together called as micro biome. The human micro biome is a source of various genetic diversity and no two human micro biomes can be absolutely same. Different microbes reside on different places of human body and they are adapted to the conditions in which they live. These microorganisms play an important role in maintaining the human health. (Kumar et al., 2017).

The hands of the human body are in most contact with the outer world. The human hands are located at the end of each arm. Normally, a human has five fingers on each hand which includes: a thumb, index finger, middle finger and little finger (Baran et al., 2002). People use their hands for multiple purposes every day. Therefore, it is very easy to come in contact with different microbes and to transfer them to objects and even to people. Surprisingly, fingernails 
are the home for most of the bacteria found on human hands (Wachukwue et al., 2017).

Fingertips are the areas of the human skin that contains the highest concentration of receptors. These areas of the nerve endings make the fingers very sensitive to heat, cold, moisture, vibration, pressure and various other stimuli (Wootton et al., 2007). Fingernails are attached to the distal end of each finger. A nail is tough envelope like covering the terminal phalanges of fingers and toes in human. (Wang et al., 2016).

The area under the fingernail is difficult to clean and therefore there resides the most pathogenic organisms. Activities which can increase the risk of bacterial nail infection include: having constantly wet hands, severe nail biting, eczema around the fingernails. It is seen that the fingernails are more sensitive to accumulate different kinds of bacterial pathogens due to constant change in the environment of the host and its surrounding. (Larson et al., 2003).

The study under this research shows the importance of Nail hygiene as there is prevalence of pathogenic bacteria under the nails which may lead to numerous health issues.

\section{MATERIAL AND METHODS}

\section{Collection of samples}

This study was conducted between august to September, 2019, at Patna women's college.

Three nail samples were collected from people of different ages in profession randomly. Normal saline $(0.9 \%)$ was prepared and sterilized in autoclave for 15 minutes at $15 \mathrm{psi}, 121{ }^{\circ} \mathrm{C}$. The swab sticks were dipped in normal saline and sterlized. The collected samples were rubbed all over the area under the nails from sterile swab sticks. The swab sticks were then dissolved in $10 \mathrm{ml}$ of normal saline mixed thoroughly in a sterilized test tube. The nutrient agar media (Aneja., 2017) was prepared in a flask and sterilized in autoclave. The prepared media was cooled (not solidified) after being sterilized. The second and third dilution was used for isolation of bacteria for all the 3 samples and plated on nutrient agar plates. The plates were incubated at $37{ }^{\circ} \mathrm{C}$ for 24 hours (Mengist et al., 2018)

\section{Isolation}

After incubation for hours, the plates were checked for their growth of bacterial colonies. Then continuous or quadrant streaking was done with the loop near the flame. The Petri plates was sealed and incubated for 24 hours at $37{ }^{\circ} \mathrm{C}$. After 24 hours the plates were observed for their growth and pure culture was obtained by streaking ( Risan et al., 2017).

\section{Identification}

Further to this Gram staining was done to identify the morphological characteristics whether it is gram positive or gram negative, the shape etc. The slide was observed in bright field microscope at 100x (oil immersion technique) and at 10x (Cohen et al., 1992).

\section{Biochemical tests}

Biochemical tests are based on the ability of the given microbes to utilize a particular chemical and respond accordingly. Structural differences are not enough to identify bacteria, as many species of the same genus can have similar shapes too. Hence, biochemical tests are used for the identification based on different activities with different biochemical compounds. Following tests were performed to identify the samples:- 


\section{Indole test}

This test is performed to check the ability of the bacterial samples to convert tryptophan into indole by an enzyme tryptophanase. The appearance of a cherry red colour indicates positive result. A negative be result is indicated by no change in the broth after addition of Kovac's reagent (Michael et. al., 1986)

\section{Citrate test}

It is based on the ability of an organism to use citrate as a source of carbon and energy. Simmon's citrate agar media was used for this test. The bacterial colonies are inoculated and incubated at $37{ }^{\circ} \mathrm{C}$ for $24 \mathrm{hrs}$. The positive be result shows the appearance of blue colour and negative test shows no change in the colour of the media (Clarke et al. 1952).

\section{Nitrate test}

This test determines the production of an enzyme nitrate reductase which reduces nitrate into nitrite. For this test a heavy inoculum is inoculated into a nitrate broth, and is incubated for $24 \mathrm{hrs}$ at $37^{\circ} \mathrm{C}$. Appearance of cherry red colour on addition of reagent $A$ and $B$ indicates positive result. No change in the colour indicates negative result to this test (Aneja ., 2018).

\section{Urease test}

This test is responded by a certain group of microorganisms which metabolize urea present in the media and convert them into ammonia and carbon dioxide in the presence of urease enzyme. During incubation the organism utilizing urea by urease enzyme which Ultimately raise the $\mathrm{pH}$ of the media which is detected by the change in colour of the media from yellow to red or deep pink. Urea must not be sterilized in an autoclave as it is unstable and breaks down at 15 psi steam pressure. $(+)$ ve result is indicated by change in color of the media from yellow to red whereas (-) ve test is indicated by no change in colour (Aneja ., 2018).

\section{Antimicrobial susceptibility test}

This test is performed by using simple disk diffusion method for both gram positive and gram negative bacteria. This method employs the phenotypic identification of susceptibility and therefore requires the following process.

The cultures were isolated carefully to prepare an inoculum. The inoculated test tubes were then incubated at 37.celsius for $24 \mathrm{hrs}$ to obtain a moderate turbidity. A sterile cotton swab was dipped into the broth and rotated firmly on the upper inside walls of the test tube. The inoculums were swabbed uniformly on NA plated under sterile condition. The inoculum was allowed to dry for and the antibiotic discs were impregnated on the surface of the plates using sterile forceps. The plates were than incubated at $37{ }^{\circ} \mathrm{C}$ for 24 hrs. The zones of inhibition were measured in millimeters (Risan et al., 2017; Aneja ., 2017).

The antibiotic disc used for checking the susceptibility of the samples were, chloromphenicol (30mcg), Ampicillin (10mcg), Norfloxacin (10mcg), Co-Trimoazol (25mcg), Ciprofloxacin (5mcg).

\section{RESULTS}

\section{Cultural characteristics}

15 to 30 bacterial colonies were observed on second dilution plated media and 6 to 9 colonies on third dilution plated media. The bacterial samples were collected from nails of various age groups like sample 1 was from a female of 38 years suffering from fungal infection in her nails, sample 2 was of a 17 year old 
boy and sample 3 was of a 12 year old girl. Isolates of Sample 1 showed the most abundant growth on nutrient agar media. Sample 2 and sample 3 isolates showed moderate growth .sample 1 culture was pured by streaking twice to get a pure colony due to heavy growth.

Table 1- cultural characteristics of the selected isolates

\begin{tabular}{|c|c|c|c|c|c|}
\hline Isolates & Colour & texture & Form & elevation & margin \\
\hline Isolate 1 & White & Dry & irregular & umbonate & wavy \\
\hline Isolate 2 & White & rough & irregular & umbonate & wavy \\
\hline Isolate 3 & Off white & Shiny & punctiform & Slightly raised & entire \\
& & & & & \\
\hline
\end{tabular}

\section{Morphological characteristics}

The following results were obtained after Gram's staining of the selected isolates as shown in the table 2 .

Table 2- Gram's stain characterization of the selected isolates

\begin{tabular}{|c|c|}
\hline Isolates & Gram's stain result \\
\hline Isolate 1 & Positive \\
\hline Isolate 2 & Positive \\
\hline Isolate 3 & Negative \\
\hline
\end{tabular}

\section{Biochemical tests :}

The isolate 1 and 2 showed orange colour in the top layer of the tube. This is a variable colour which is formed due to the presence of skatole, also called methylated indole which is another possible product of indole degradation. Isolate 3 showed positive red colour in the surface of alcohol layer of broth .

The second biochemical test done was citrate utilization test. Isolate 1 and 2 were slightly positive as it was not totally blue while sample was totally positive as it showed fully blue colour slant. The isolate 3 showed no change in colour of the slant and remained green in colour, therefore it gave citrate negative test.

The third test done was nitrate reduction test which is based on the detection of nitrite and its ability to form red compound when it reacts with sulfanilic acid to form a complex nitrite sulfanilic acid which further reacts to give alpha napthylamine to give prontosil, a red precipitate which is water soluble which was given by isolate 1, 2 and 3 all detecting positive tests for nitrate reduction.

Fourth test followed was urease test. All the three isolates gave a negative test for urease which shows 
that bacteria is lacking in production of urease. The bacterial species were identified on the basis of
Gram's stain result however for confirmation $16 \mathrm{~s}$ rRNA sequencing is required.

Table 3- biochemical characterization of the selected isolates

\begin{tabular}{|c|c|c|c|}
\hline $\begin{array}{c}\text { Biochemical } \\
\text { test/isolate }\end{array}$ & Bacillus spp. & Bacillus spp. & Escherichia spp. \\
\hline Indole test & Negative & Negative & Positive \\
\hline Citrate test & Slightly positive & Slightly positive & Negative \\
\hline Nitrate reduction test & Positive & Positive & Positive \\
\hline Urease test & Negative & Negative & Negative \\
\hline
\end{tabular}

\section{Antimicrobial susceptibility tests}

The antimicrobial susceptibility tests were performed by disk diffusion agar method to check the resistance to various antimicrobial compounds which are further useful in treatment of diseases. The presence or the absence of growth in the area surrounding the disk indirectly indicates the ability of the microorganism to inhibit the organism. Therefore 5 antimicrobial compound disks were used which are as follows: ampicillin, chloromphenicol, norfloxacin, Co-trimoxazol and ciproflaxin (Mengist et al., 2018). The zone formation by all these compounds is depicted in the table in the next page. The zone measure was taken in millimeters. The results were calculated based on standards .both the samples were sensitive to all the antimicrobial compounds except ampicillin. Since isolate 1 and 2 had 11.1 and $11 \mathrm{~mm}$ as diameter which was less than 13 , therefore it indicated to be resistant. Isolate 3 had no zone formation so it proved to be sensitive. In case of chloromphenicol the diameters were far more than 18 $\mathrm{mm}$ which shows that the bacterium was susceptible (Hedderwick et al., 2007). The samples were susceptible to Norfloxacin as their diameters were greater than $17 \mathrm{~mm}$. The samples were susceptible to Co-trimoxazol and ciproflaxin as well as their diameters were far greater than standardized (Risan et al., 2017).Also the results so obtained were compared with CLSI standard.

Table 4- Antimicrobial susceptibility test results for Bacillus spp., Bacillus spp., Escherichia spp. respectively

\begin{tabular}{|c|c|c|c|c|c|c|}
\hline Antibiotic & $\begin{array}{c}\text { Disc amount } \\
(\text { microgram) }\end{array}$ & $\begin{array}{c}\text { Zone of } \\
\text { resistance } \\
(\mathrm{mm})\end{array}$ & $\begin{array}{c}\text { Zone of } \\
\text { intermediate } \\
(\mathrm{mm})\end{array}$ & $\begin{array}{c}\text { Zone of } \\
\text { susceptible } \\
(\mathrm{mm})\end{array}$ & $\begin{array}{c}\text { Zone } \\
\text { diameter } \\
\text { formed } \\
(\mathrm{mm})\end{array}$ & Inference \\
\hline Ampicillin (AM) & 10 & $<$ or $=13$ & $14-16$ & $>$ or $=17$ & 11.1 & Resistant \\
\cline { 2 - 7 } & 10 & $<$ or $=13$ & $14-16$ & $>$ or $=17$ & 11 & Resistant \\
\cline { 2 - 7 } & 10 & $<$ or $=13$ & $14-16$ & $>$ or $=17$ & 0 & Resistant \\
\hline Norfloxacin (NF) & 10 & $<$ or $=12$ & $13-16$ & $>$ or $=17$ & 30 & Susceptible \\
\cline { 2 - 7 } & 10 & $<$ or $=12$ & $13-16$ & $>$ or $=17$ & 30 & Susceptible \\
\hline
\end{tabular}




\begin{tabular}{|c|c|c|c|c|c|c|}
\hline & 10 & $<$ or $=12$ & $13-16$ & $>$ or $=17$ & 27 & Susceptible \\
\hline $\begin{array}{c}\text { Chloramphenicol } \\
(\mathrm{C})\end{array}$ & 10 & $<$ or $=12$ & $13-17$ & $>$ or $=18$ & 23 & Susceptible \\
\cline { 2 - 7 } & 10 & $<$ or $=12$ & $13-17$ & $>$ or $=18$ & 22.8 & Susceptible \\
\cline { 2 - 7 } & 10 & $<$ or $=12$ & $13-17$ & $>$ or $=18$ & 26 & Susceptible \\
\hline \multirow{3}{*}{$\begin{array}{c}\text { Ciprofloxacin } \\
(\text { CIP-5) }\end{array}$} & 5 & $<$ or $=15$ & $16-20$ & $>$ or $=21$ & 39 & Susceptible \\
\cline { 2 - 7 } & 5 & $<$ or $=15$ & $16-20$ & $>$ or $=21$ & 39 & Susceptible \\
\cline { 2 - 7 } & 5 & $<$ or $=15$ & $16-20$ & $>$ or $=21$ & 29 & Susceptible \\
\hline \multirow{3}{*}{$\begin{array}{c}\text { Co-Trimoxazole } \\
(T M)\end{array}$} & 25 & $<$ or $=10$ & $11-15$ & $>$ or $=16$ & 26.9 & Susceptible \\
\cline { 2 - 7 } & 25 & $<$ or $=10$ & $11-15$ & $>$ or $=16$ & 27 & Susceptible \\
\cline { 2 - 7 } & 25 & $<$ or $=10$ & $11-15$ & $>$ or $=16$ & 29 & Susceptible \\
\hline
\end{tabular}

\section{IV.DISCUSSION}

The bacterial pathogen found under the human nails are found to be resistant to many antibiotics. Nails are considered to be the home of many bacteria and these pathogens can be transmitted to healthy individuals and can even worsen a patient existing medical condition. The pathogenicity and virulence of these bacteria is associated with its capacity to produce several virulence factors. Antibiotic susceptibility test was performed via the disk diffusion agar method tests in order to determine which antimicrobials will inhibit the growth of the bacteria causing a specific function. The gram-negative disc and gram-positive disc were used against the bacterial isolates according to the gram reaction. Plates are incubated for 24 hours at 37o C. The antibiotics used in this study includes ampicillin, chloramphenicol, norfloxacin, co-trimoxazole, ciprofloxacin. The result of the antibiotic susceptibility test of the isolates showed that the gram-negative species is found to be $80 \%$ susceptible to all the antibiotics used whereas no zone of inhibition is seen where the ampicillin disc is used, this showed that the species is resistant to ampicillin. Trimoxazole as well as ciprofloxacin showed the high inhibitory activity and is effective. The gram-positive species are $80 \%$ susceptible to the antibiotics used whereas ampicillin was resistant. Ciprofloxacin showed the highest inhibitory action on the grampositive isolates and is very effective. These information are used to select an appropriate antibiotics to fight a specific infection. The result obtained was in accordance with Risan et al., 2017 however the result differed with Mengist et al., 2018. This study conducted showed that the fingernails contains a lot of pathogenic bacteria and the unhygienic nails can serve as a medium for transmitting many harmful bacteria to healthy individuals (Prescott et al., 2005). Nail hygiene is becoming an important aspect in our day to day lives. Nail hygiene etiquettes are a major factor which are taken into consideration by the professional medical practitioner as untidy nails can worsen a patient's existing medical conditions. It is extremely important to keep the nails and the area under the nails clean because surprisingly, fingernails are the home of the many bacterial pathogen. However, it is difficult to clean to area under the fingernails as compared to the other body parts. Fingernails are more susceptible to the constant changing environment of the host and its environment (Brannon et al., 2008).

This study conducted showed the importance of nail hygiene as many bacteria resides on our nails. Chewing on nails directly puts those harmful bacteria in our mouth. These bacteria are also responsible for many of the disease caused in humans (Wootton et al., 2019). Transmission of these bacteria occurs through food, water and even fingers. The food handlers accumulate many such bacterial pathogen and 
contaminate food by their fingers and then to food preparation and serving. Thus, infecting healthy persons. Bacillus spp. bacterium is a common cause of most of the bacterial infection of the nail (Hunter et al., 2002).

\section{v. CONCLUSION}

This study was conducted to isolate and identify bacteria from human finger nails. The isolated pathogens from finger nails included Bacillus species (2 isolates), coccus species (one isolate). Highest contamination of Bacillus species was isolated. After isolation further characterization on the basis of biochemical characteristics including Indole test, Citrate test, Nitrate reduction test and Urease test; based on these tests and ABIS results possible microorganisms indicating isolate one and two can be Bacillus licheniformis (similarity 94.1\%), Bacillus cerus (similarity 94.\%), Bacillus thuringensis (similarity $94.1 \%$ ) or Bacillus mycoides (similarity 92.3\%) where as isolate three can be Escherichia coli (similarity 99\%), Escherichia fergusonii (similarity 98\%). After that Antimicrobial susceptibility tests were performed to identify the resistance of a particular bacteria towards a given antibiotic based on CLSI standards i.e. Ampicillin, Chloromphenicol, Norfloxacin, Co-Trimoxazol and Ciprofloxacin which showed that isolate one and two were susceptible to 4 antibiotics and resistant to one. The resistant group as as indicated by ABIS online was beta-lactans where as suspectible groups indicated were quinolones and phenicols for isolate one and two. Hence the results obtained showed the resistance of isolates towards Ampicillin indicating the prevalance of potentially disease causing microbes under fingernails. This study showed the importance of nail hygiene as pathogenic microorganisms prevail under our nails which is needs our attention for healthy life.

\section{VI.ACKNOWLEDGEMENT}

First and foremost, we would like to express our gratitude towards the almighty for his blessings at every step without which nothing could be accomplished.

We express our thanks to Department of Biotechnology (DBT) Gov. of India, for granting us the permission to carry our research work.

We are highly indebted to thank our Principal Sister M. Rashmi A.C for giving us an opportunity to be a part of this project under the star college scheme of DBT.

We extend our gratitude to Dr. Jaya Philip, coordinator, Department of Microbiology, and supervisor of our DBT project for her whole hearted co-operation and supervision and for imparting valuable information.

We express our special gratitude and thanks to Vijay Kumar Mishra for the support and all the laboratory staff and assistants for giving us such attention and time and also highly thankful to our respected teachers of the department for their kind guidance.

\section{VII.REFERENCES}

[1]. Aneja K., (2017). Experiments in microbiology, plant pathology, tissue culture and microbial biotechnology. 5th ed. New age international publishers. New Delhi. pp. 240-268.

[2]. Aneja K., (2018). Laboratory manual of microbiology and biotechnology. 2nd ed. New age international publishers. New Delhi. pp. 242270. 
[3]. Baran R., (2002). Nail healthy therapy: an attractive enhancement or a potential hazard. Journal of cosmetics and dermatology,1:24-29.

[4]. Brannon M., Heather D., (2008). Nail anatomy. Journal of dermatology,122(7):192-199.

[5]. Clarke, P.H., and S.T. Cowan. Biochemical methods for bacteriology. J. Gen. Microboil. 1952: 6:187-197

[6]. Cohen., Philip R., Richard K., (1992). Nail disorders: diagnosis and treatment. Journal of the American academy of dermatology.26(4):521531.

[7]. Hedderwick S., Shelly M., Micheal L., Carol K., (2007). Pathogenic organisms associated with artificial fingernails worn by healthcare workers, journal of infection control and hospital epidemiology,21:505-509.

[8]. Hunter J., Savin J., and Dahl M., (2002). Clinical dermatology. Malden, Mass; Blackwell sciences. pp. 173.

[9]. Kumar A., Chordia N., (2017). Role of microbes in human health. Applied microbiology: open acess,3(2):2471-9315.

[10].Larson E., (2001). Hygiene of skin: when is clean too clean? Journal of emerging infectious diseases,7(2):12-17.

[11].Mengist A., Aschale Y., Reta A., (2018). Bacterial and parasitic assessment from fingernail in Debre markos, northwest Ethiopia. Canadian journal of infectious disease and medical microbiology.

[12].Michael j. Pelczar., ECS Chan, Noel R. Krieg.McGraw company New York Fifth editin. 1986: 597.

[13].Prescott L., Harley P., Kelvin D., (2005). Microbiology. 6th ed. Tim McGraw Hill co. New Delhi. pp: 675.

[14].Risan., Hasim., Mohsen., (2017). Isolation and identification of bacteria from under fingernails. International journal of current microbiology and applied science. pp:3584-3590.
[15].Wachukwu C., Abbey S., Obilor L., (2007). Public health implication of artificial finger nails used by health workers and food handlers. Journal of applied science,7(22):3580-3583.

[16].Wang B., Johnson A., (2016). keratin: structure, mechanical properties, occurrence in biological organisms, and efforts at bioinspiration.76: 229318.

[17].Wootton M., Brown N., Glynn G., Teale C., (2019). BSAC methods for antimicrobial testing. BSAC British society for antimicrobial chemotherapy. pp.18-25.

\section{Cite this article as :}

Saloni Singh, Dr. Jaya Philip, Kumari Nidhi, Pallavi Kumari, Shagufta Akhtar, Khushboo Kumari, "Identification of Bacteria from under Finger Nails", International Journal of Scientific Research in Science and Technology (IJSRST), Online ISSN : 2395-602X, Print ISSN : 2395-6011, Volume 7 Issue 6, pp. 234-241, November-December 2020. Available at doi : https://doi.org/10.32628/IJSRST207629 Journal URL : http://ijsrst.com/IJSRST207629 